\title{
ANELASTIC BEHAVIOUR OF POLYCRYSTALLINE ICE
}

\author{
By Paul Duval \\ (Laboratoire de Glaciologie, C.N.R.S., B.P. 53, F-38041 Grenoble-cedex, France)
}

\begin{abstract}
Torsion creep tests were performed on glacier ice at temperatures above $-12^{\circ} \mathrm{C}$. The polycrystalline ice, when unloaded, exhibits creep recovery. The time-dependent recoverable component of deformation (or anelastic strain) $\epsilon_{\mathrm{a}}$ was found to be adequately described by a relationship of the form: $\epsilon_{\mathrm{a}}=\Delta \tau \log (\mathrm{I}+\alpha t) / h$, where $\Delta \tau$ is the stress decrement, $\alpha$ a constant, and $t$ the time. The anelastic modulus $h$ defined for times $t$ in excess of $3 \mathrm{~h}$ is always smaller than the dynamic elastic modulus. The movement of dislocations composing the sub-boundaries or in dislocation pile-ups may produce this important reversible deformation. The time-dependent recovery is explained in a similar way to the transient creep behaviour observed at low temperatures for metals. The small temperature dependence of creep recovery would arise from the existence of a distribution of internal stresses values.
\end{abstract}

RÉsumé. Comportement anélastique des glaces polycristallines. Des expériences de fluage en torsion pure ont été réalisées sur des glaces de glaciers à des températures supérieures à - $12{ }^{\circ} \mathrm{C}$. A la décharge, une restauration du fluage est trouvée pour les glaces polycristallines. La composante de la déformation restaurée, dépendant du temps (ou déformation anélastique) $\epsilon_{\mathrm{a}}$ est correctement décrite par la relation $\epsilon_{\mathrm{a}}=$ $\Delta \tau \log (\mathrm{I}+\alpha t) / h$, où $\Delta \tau$ est la contrainte résultant de la décharge et $t$ le lemps. Le module anélastique $h$ défini pour des temps $t$ supérieurs à $3 \mathrm{~h}$ est toujours plus petit que le module élastique dynamique. Le mouvement des dislocations composant les sous-joints ou les empilements de dislocations peut être à l'origine de cette importante déformation réversible. La restauration dépendant du temps est expliquée de la même façon que le fluage transitoire obtenu à basse température pour les métaux. Une distribution des contraintes internes serait à l'origine de la faible dépendance du fluage réversible avec la température.

Zusammenfassung. Anelastisches Verhalten von polykristallinem Eis. An Gletschereis wurden Torsionskriechversuche bei Temperaturen oberhalb $-12^{\circ} \mathrm{C}$ ausgeführt. Die polykristallinen Eisproben zeigen nach Entlastung Kriecherholung. Der zeitabhängige erholungsfähige Anteil der Verformung (anelastische Verformung) $\epsilon_{\mathrm{a}}$ wurde angemessen beschrieben durch eine Beziehung der Form: $\epsilon_{\mathrm{a}}=\Delta \tau \log (\mathrm{I}+\alpha t) / h$, dabei ist $\Delta \tau$ der Spannungsabfall, $\alpha$ eine Konstante und $t$ die Zeit. Der anelastische Modul $h$, der für Zeiten $t$ oberhalb oberhalb $3 \mathrm{~h}$ bestimmt wurde, ist stets kleiner als der dynamische elastische Modul. Die Bewegung von Versetzungen, welche Sub-Korngrenzen oder. Versetzungstaus bilden, können diese bedeutende reversible Verformung hervorrufen. Die zeitabhängige Erholung wird in ähnlicher Weise wie das Übergangskriechverhalten erklärt, das bei niederen Temperaturen an Metallen beobachtet wurde. Die geringe Temperaturabhängigkeit der Kriecherholung könnte von dem Vorhandensein einer inneren Spannungsverteilung herrühren.

\section{INTRODUCTION}

The application of a stress to a polycrystalline ice sample results in a total strain that is often time dependent. The accumulated strain is described by the equation

$$
\epsilon=\epsilon_{0}+\epsilon_{\mathrm{t}}+\dot{\epsilon}_{\mathrm{s}} t,
$$

where $\epsilon_{0}$ is the instantaneous strain on loading, $\epsilon_{\mathrm{t}}$ the limiting transient creep and $\dot{\epsilon}_{\mathrm{S}}$ the secondary creep-rate. The second creep component changes when recrystallization processes occur (Glen, i955). Glen ( 1955) found that for polycrystalline ice tested near the melting point, the transient creep strain could be approximated by Andrade's law:

$$
\epsilon_{\mathrm{t}}=\beta t^{\frac{1}{3}} \text {. }
$$

Equation (2) has also been confirmed by Duval (I977).

When unloaded, ice exhibits creep recovery (Jellinek and Brill, I956). So a more realistic approach should be made in describing the ice creep deformation by the incorporation of anelastic contributions to the transient behaviour. Anelastic strains are the time-dependent component of deformation recoverable after release of the stress, and like elastic strains their magnitude is most frequently linearly related to stress change (Nir and others, I976; Lloyd and McElroy, I 976). The values of anelastic strains are typically of the same order of magnitude as the elastic strains (Friedel, I 956; Jellinek and Brill, 1956).

If the anelastic contribution is included, the relationship for creep is given by:

$$
\epsilon=\epsilon_{0}+\epsilon_{\mathrm{a}}+\epsilon_{\mathrm{t}}+\dot{\epsilon}_{\mathrm{s}} t,
$$

where $\epsilon_{\mathrm{a}}$ is the anelastic strain and $\epsilon_{\mathrm{t}}$ becomes the unrecoverable transient creep. 
The purpose of the present study was to investigate the anelastic strain in polycrystalline ice deformed in shear over a range of temperatures and stresses, and to establish the time law of recovery.

\section{EXPERIMENTAL METHODS}

\section{Ice samples}

The behaviour of different natural polycrystalline ices was investigated.

I. Ice from the Vallée Blanche (French Alps)

The sample cores come from a drilling carried out through the whole thickness of the glacier $(187 \mathrm{~m})$. Only ice down to the depth of $180 \mathrm{~m}$ was studied (the sample reference was: V.B. I8o). This ice, of grain size of about $\mathrm{I} \mathrm{cm}$, was without bubbles. The $c$-axis fabrics consisted of four maxima (Vallon and others, 1976).

2 .Ice from Terre Adélie (Antarctica)

During 1973, a hole $303 \mathrm{~m}$ deep was drilled near station D ro (distance to the coast: $5 \mathrm{~km}$ ). Several samples were investigated in this study. Temperature in the ice was $-4^{\circ} \mathrm{C}$ in the upper layer and reached $-7^{\circ} \mathrm{C}$ at the bottom. The crystal size of ice studied was always smaller than $1.4 \mathrm{~cm}$.

\section{Experimental procedure}

Specimens in the shape of a hollowed-out cylinder (external diameter 90 to $100 \mathrm{~mm}$, internal diameter about $30 \mathrm{~mm}$, height about $130 \mathrm{~mm}$ ), were prepared. Torsion creep tests were carried out at temperatures of $-\mathrm{I} 2{ }^{\circ} \mathrm{C}$ and $-\mathrm{I} .5^{\circ} \mathrm{C}$ over a range of stresses from $3^{\circ}$ to $370 \mathrm{kN} / \mathrm{m}^{2}$ using a constant-stress machine (Duval, unpublished). The shear stress $\tau$ was calculated by assuming the validity of Glen's law with $n=3$. The values quoted were calculated for the outer surface of the cylinder.

The loading unit was housed in a cold room the temperature of which was maintained at $-\mathrm{I} 4{ }^{\circ} \mathrm{C}$. A regulation system inherent in the apparatus allowed one to reach the required temperature. The maximum variation of sample temperature during an experiment was $0.2^{\circ} \mathrm{C}$.

Strain was measured as a function of time by linear variable differential transformer transducers (L.V.D.T.) and the output was recorded continuously. The sensitivity of strain measurements was approximately $\mathrm{ro}^{-5}$.

\section{ExPERIMENTAL RESULTS}

\section{Strain-time relationship during unloading}

Figure I shows typical results for the creep recovery strain plotted against the logarithm of the time after $100 \%$ stress reduction during secondary creep. The same specimen was used for measurements at shear stress of $200 \mathrm{kN} / \mathrm{m}^{2}$ and $130 \mathrm{kN} / \mathrm{m}^{2}$. The anelastic strains $\epsilon_{\mathrm{a}}$ are adequately described by the relationship

$$
\epsilon_{\mathrm{a}}=k \log (\mathrm{I}+\alpha t),
$$

where $t$ is the time after unloading and $k$ and $\alpha$ are constants. Equation (4) was found to hold for times in excess of $3 \mathrm{~h}$ providing this followed a loading period in excess of $\approx 6 \mathrm{~h}$ (i.e. before secondary creep).

Over the range of stresses investigated, the constant $k$ is proportional to the shear stress decrement $\Delta \tau$. So anelastic strain is given by

$$
\epsilon_{\mathrm{a}}=\Delta \tau \log (\mathrm{I}+\alpha t) / h .
$$

With this linear relationship and for defined recovery times, the quantity $h$ can be defined as the anelastic modulus (Lloyd and McElroy, 1976). 


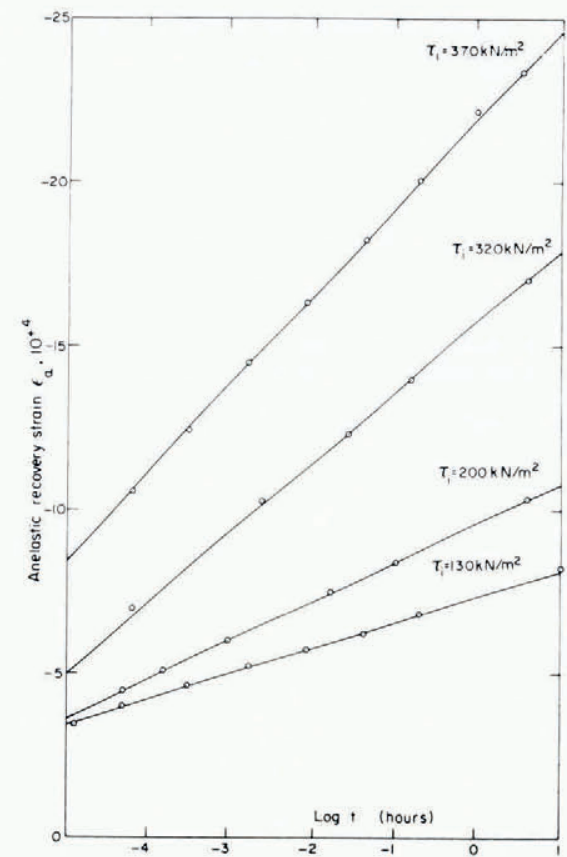

Fig. I. Anelastic recovery strain as a function of $\log t$ after pre-strains for different values of shear stress. Samples $: V . B .180$. Temperature $T=-1.5^{\circ} \mathrm{C}$.

The anelastic strain does not change with the loading period during secondary creep; but, as shown in Figure 2, it increases with pre-strain during primary creep. The three curves shown on Figure 2 were obtained with the same specimen; the recovery period was always three times the loading period.

The anelastic modulus calculated for recovery times in excess of $3 \mathrm{~h}$ is always smaller than the elastic modulus measured by dynamic methods. For frequencies greater than $\mathrm{roo} \mathrm{Hz}$, characteristic values of elastic modulus are of about $9000 \mathrm{MN} / \mathrm{m}^{2}$ (Nakaya, I959). From the results shown in Figure $\mathrm{I}$, the anelastic moduli are of one order of magnitude less than the elastic moduli.

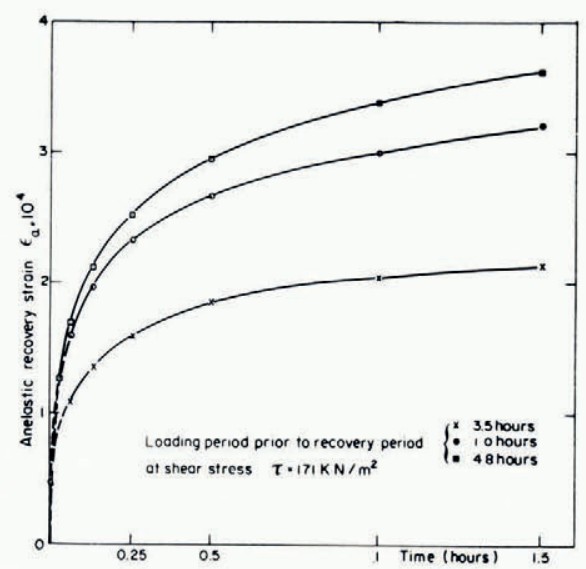

Fig. 2. Anelastic recovery strain as a function of time after various prestrains for shear stress $=I 7 I \quad k . V / m^{2}$. Sample: D.IO $\left(\right.$ I0o.66 m). Temperature $T=-I .5^{\circ} \mathrm{C}$. 
Other measurements were made on natural ice from Antarctica. The results are shown in Table I. The anelastic modulus varies with the origin of the samples, but is always smaller than the dynamic modulus. So it appears that the anelastic contribution cannot be neglected in the creep equation (Equation (3)), in spite of the influence of pre-strain during primary creep.

TABle I. REsults OF RECOVERy TESTS

Samples: ice from D. ro station (Antarctica) at various depths Test temperatures: $-\mathrm{I} .5+0.1^{\circ} \mathrm{C}$

The anelastic moduli were calculated for recovery times of $3 \mathrm{~h}$ Loading period prior to recovery period: $48 \mathrm{~h}$

$\begin{array}{cccc}\begin{array}{c}\text { Depth in the glacier } \\ \mathrm{m}\end{array} & \begin{array}{c}\text { Grain size } \\ \mathrm{cm}\end{array} & \begin{array}{c}\text { Shear stress } \\ \mathrm{kN} / \mathrm{m}^{2}\end{array} & \begin{array}{c}\text { Anelastic modulus } \\ \mathrm{MN} / \mathrm{m}^{2}\end{array} \\ 46.13 & 0.4 & 140 & 680 \\ 100.66 & 0.7 & 17 \mathrm{1} & 430 \\ 127.53 & 1.0 & 160 & 205 \\ 247.00 & 1.3 & 177 & 550\end{array}$

\section{Effect of temperature}

Figure 3 shows the variation of shear strain-rate with time at two temperatures for two samples during primary and steady-state creep. The first part is transient creep, which corresponds to the recovery creep, and is very little temperature dependent. This result contrasts with that concerning secondary creep for which the activation energy is greater than $80 \mathrm{~kJ} / \mathrm{mol}$ in the same range of temperature (Glen, I955).

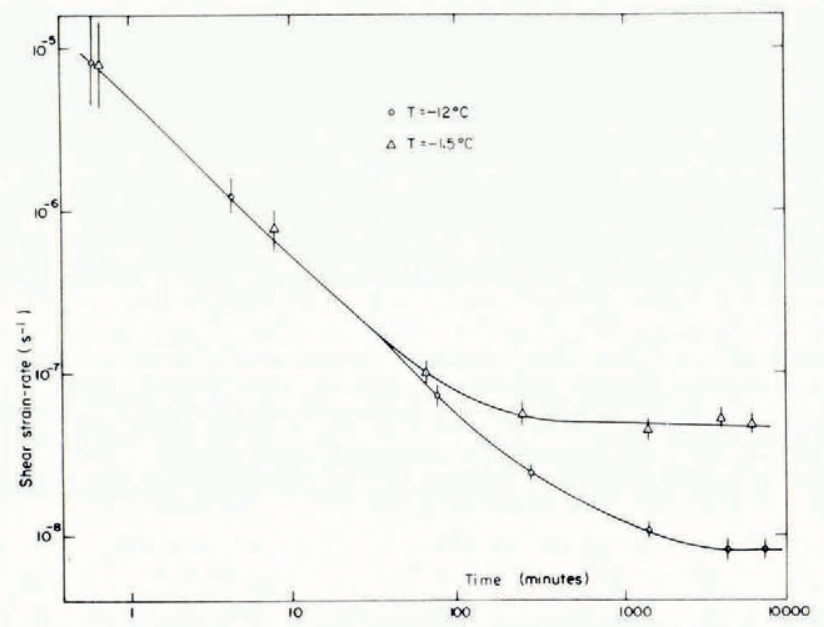

Fig. 3. Shear strain-rate as a function of time during creep tests at $-I 2^{\circ} \mathrm{C}$ and $-\mathrm{I} .5^{\circ} \mathrm{C}$ and for shear stress $\tau=3 \mathrm{IO} \mathrm{kN} / \mathrm{m}^{2}$. Samples: V.B. I80.

\section{Discussion}

Low values of anelastic modulus

For the glacier ice studied, experimental results show clearly that the anelastic modulus is always much smaller than the elastic modulus measured at high frequencies (Nakaya, I959). Glen (r955) observed that a stress decrease during a creep test is followed by a strain diminution much greater than the expected elastic contribution. However, for fine-grained polycrystalline ice and low stresses, the anelastic moduli calculated by Jellinek and Brill (1956) 
were always of the same order of magnitude as the dynamic clastic modulus. A strong drop of Young's modulus was also observed in polygonized coarse-grained aluminium by Friedel and others (1955). This drop of modulus was attributed to displacements of the dislocation walls of the polygonized structure. A much smaller anomaly of elastic modulus is expected if the dislocations form a network in the bulk of the crystal (Friedel, i956). The dislocation substructure observed by Fukuda and Higashi (1969) in ice single crystals from Mendenhall Glacier (a temperate glacier) could explain the low values of anelastic modulus. But, in addition to the unbowing of dislocations in sub-boundaries, one could also consider the runback of dislocations piled up against grain boundaries or other obstacles.

\section{Strain-time relationship}

The logarithmic time law for the strain recovery was explained by Duval (1977), by the same model as generally adopted for the transient creep in metals deformed at low temperatures. This model is based upon the competition between work hardening and recovery. During transient creep, the strain-hardening rate exceeds the recovery rate or, in like manner, the average internal stress opposing dislocation motion, increases. Upon unloading, the dislocation motion is explained by relaxation of internal stresses. Traetteberg and others (1975) suggested that the non-elastic behaviour was determined by two or more relaxation times. In fact, the logarithmic law implies a distribution of relaxation times.

Equation (5) has not been verified for small stresses. However the transients observed after a small stress decrease during secondary creep show that anelastic strain must be very small for stresses lower than $50 \mathrm{kN} / \mathrm{m}^{2}$ (Duval, 1977). The results found by Jellinek and Brill ( $195^{6}$ ) for shear stresses smaller than $150 \mathrm{kN} / \mathrm{m}^{2}$ support this inference.

\section{Creep recovery and internal friction}

The creep recovery, treated as an anelastic process, leads to the possibility that the method may be analysed like internal friction process. In creep-recovery tests, the unloading period constitutes only one-quarter of a cycle in the context of internal friction. The effective frequency of creep recovery tests would be typically of about $10^{-5} \mathrm{~Hz}$. In a wide range of materials there is a rapid rise in internal friction at high temperatures which follows a law of the type:

$$
q^{-1}=A \exp [-U / k T]
$$

where $q^{-1}$ is the internal friction. $U$ the apparent activation energy, and $A$ a structuresensitive term. This behaviour was observed in ice single crystals as well as in polycrystalline samples (Kuroiwa, I964; Vassoille and others, I974).

With the assumption that the dislocation velocity is proportional to the effective stress defined by:

$$
\sigma_{\mathrm{e}}=\sigma_{\mathrm{a}}-\sigma_{\mathrm{i}},
$$

where $\sigma_{\mathrm{a}}$ is the applied stress and $\sigma_{\mathrm{i}}$ the average internal stress, the internal friction is given by:

$$
q^{-1}=B\left[f \exp \left(U_{0} / k T\right)\right]^{-n},
$$

where $f$ is the frequency, $U_{0}$ the true activation energy for the process controlling the dislocation motion, and $B$ and $n$ are constants. This form for the internal friction implies a not-toowide distribution function for internal stresses (Schoek and others, 1964).

From Equations (6) and (7), it follows that:

$$
U=n U_{0} \text {. }
$$

The activation energy $U_{0}$, measured by Maï (1976) on monocrystals, is about $0.6 \mathrm{eV}$ for applied stresses smaller than $200 \mathrm{kN} / \mathrm{m}^{2}$, but, in this case, the applied stress corresponded to the effective stress. 
The value of $n$ can be found from the frequency dependence of the internal friction $q^{-1}$. For different pure metals and alloys, the value of $n$ is about 0.2 (Batist, 1969; Lloyd and McElroy, 1976). On the other hand, the properties of transient creep and internal friction were correlated by Lomnitz ( 1957 ) on the basis of a linear theory. According to this author, a creep function of logarithmic type implies that internal friction is nearly constant for frequencies smaller than $10^{-2} \mathrm{~Hz}$. So, the value of $n$ of Equation (7) should be very small for the creep-recovery tests. This result explains the very small temperature dependence of transient creep and shows that the activation energy for secondary creep corresponds to that of the recovery rate (Duval, I977).

From Equation (7), we can see that internal friction increases when the frequency decreases. This result should explain the difference between the values of the dynamic elastic modulus and those of the anelastic modulus found in this study.

Vassoille and others (1974) observed that the level of background damping was higher for polycrystalline ice than for ice single crystals. We think that the high-temperature background has the same origin for polycrystalline ice and for ice single crystals. The plastic anisotropy of ice crystals and grain-boundary sliding favour the bending of basal planes in polycrystalline ice, with the formation of many small angle boundaries (Gold, I963). Obviously, these obstacles to slip do not exist in ice single crystals deformed by sliding in the basal plane. Traetteberg and others ( 1975) observed that Young's modulus of both granular and columnar-grained ice undergoes a relaxation in the range of strain-rates studied. But Young's modulus of columnar grained ice was always greater than that of granular ices.

\section{Conclusion}

Experimental results show that anelastic strain must be taken into account in the constitutive relations for the non-elastic deformation of ice. The variation of anelastic strain with frequency explains the discrepancies found in internal-friction and creep-recovery tests.

The anelastic strain contribution corresponds to the first part of creep curve. The linear relationship between anelastic strain and stress show that recovery processes do not intervene during the first part of transient creep. This supports the interpretation given by Weertman (1973) of the first-power creep observed by many investigators in experiments carried out at low stresses.

Reversible motion of dislocations composing the sub-boundaries or of pile-ups of dislocations may explain the importance of anelasticity in ice. Following the model proposed for Andrade creep and secondary creep, strain is caused by dislocation movement but the strainrate is controlled by recovery processes.

\section{Acknowledgements}

I am very grateful to Professor Lliboutry for having guided this work and provided advice and critical comments. I would especially like to acknowledge technical assistance from A. Chaillou. I also thank the Centre National de la Recherche Scientifique, Terres Australes et Antarctiques Françaises, and Expéditions Polaires Françaises, for financial support.

\section{REFERENGES}

Batist, R. de. 1969. Internal friction of iron-chromium alloys in the temperature range between 20 and $800^{\circ} \mathrm{C}$. Fournal of Nuclear Materials, Vol. 31, No. 2, p. 307-15.

Duval, P. 1977. Lois de fluage transitoire ou permanent de la glace polycristalline pour divers états de contrainte. Annales de Géophysique, Tom. 32, No. 4, 1976, p. 335-50.

Duval, P. Unpublished. Fluage et recristallisation des glaces polycristallines. [D. d'État thesis, Université Scientifique et Médicale de Grenoble, 1976.] 
Friedel, J. 1956. Les dislacations. Paris, Gauthier-Villars. (Monographs de Chimie Physique.) [First English edition translated by L. F. Vassamillet, Oxford, etc., Pergamon Press, 1964 (International Series of Monographs on Solid State Physics, Vol. 3.), from this edition.]

Friedel, J., and others. 1955. Constantes élastiques et frottement intérieur de l'aluminium polygonisé, [par] J. Friedel, C. Boulanger et C. Crussard. Acta Metallurgica, Vol. 3 , No. 4, p. 380-9I.

Fukuda, A., and Higashi, A. I969. X-ray diffraction topographic studie; of dislocations in natural large ice single crystals. Japanese Journal of Applied Physics, Vol. 8, No. 8, p. 993-99.

Glen, J. W. 1955. The creep of polycrystalline ice. Proceedings of the Royal Society of London, Ser. A, Vol. 228, No. ${ }^{1} 175$, p. 519-38.

Gold, L. W. 1963 . Deformation mechanisms in ice. (In Kingery, W. D., ed. Ice and snow; properties, processes, and applications: proceedings of a co iference held at the Massachusetts Institute of Technology, February 12-16, I962. Cambridge, Mass., M.I.T. Press, p. $215^{-25}$.)

Jellinek, H. H. G., ant Brill, R. 1956. Viscoelastic properties of ice. Journal of Applied Physics, Vol. 27, No. 10, p. I I $9^{8-209 .}$

Kuroiwa, D. 1964. Internal friction of ice. Contributions from the Institute of Low Temperature Science, Hokkaido University (Sapporo), Ser. A, No. 18.

Lloyd, G. J., and McElroy, R. J. 1976. Creep recovery, internal friction and stress relaxation. Acta Metallurgica, Vol. 24, No. 2, p. III-15.

Lomnitz, C. 1957. Linear dissipation in solids. Fournal of Applied Physics, Vol. 28, No. 2, p. 20 I-05.

Maï, C. 1976. Etude par topographie X du comportement dynamique des dislocations dans la glace Ih. Comptes Rendus Hebdomadaires des Séances de l'Académie des Sciences (Paris), Sér. B, Tom. 282, No. 22, p. $55^{1} 5^{-18}$. Nakaya, U. I959. Visco-elastic properties of snow and ice in the Greenland ice cap. U.S. Snow, Ice and Permafrost
Research Establishment. Research Report 46.

Nir, N., and others. 1976. Anelastic deformation of high parity aluminum at room temperature, [by] N. Nir, E. W. Hart and C.-Y. Li. Scripta Metallurgica, Vol. 1o, No. 2, p. 189-94.

Schoek, G., and others. I964. The activation energy of high temperature internal friction, [by] G. Schoek, E. Bisogni, J. Shyne. Acta Metallurgica, Vol. 12, No. 12, p. 1466-68. [Letter.]

Traetteberg, A., and others. 1975. The strain rate and temperature dependence of Young's modulus of ice, [by] A. Traetteberg, L. W. Gold, R. [M. W.] Frederking. (In Frankenstein, G. E., ed. Proceedings, third International Symposium on Ice Problems, 18-2I August 1975, Hanover, New Hampshire. [Hanover, N.H.], International Association of Hydraulic Research. Committee on Ice Problems, p. 479-86.)

Vallon, M., and others. 1976. Study of an ice core to the bedrock in the accumulation zone of an Alpine glacier, by M. Vallon, J.-R. Petit and B. Fabre. Fournal of Glaciology, Vol. i 7, No. 75, p. 13-28.

Vassoille, R., and others. ${ }_{1974}$. Comportement anélastique de la glace aux faibles fréquences de sollicitation, [par] R. Vassoille, J. Tatibouët, J. Perez et P.-F. Gobin. Comptes Rendus Hobdomadrires des Séances de l'Académie des Sciences (Paris), Sér. B, Tom. 278, No. 10, p. 409-12.

Weertman, J. r973. Creep of ice. (In Whalley, E., and others, ed. Physics and chemistry of ice: papers presented at the Symposium on the Physics and Chemistry of Ice, held in Ottawa, Canada, 14-13 August 1972. Edited by E. Whalley, S. J. Fones, L. W. Gold. Ottawa, Royal Society of Canada, p. 320-37.)

\section{DISCUSSION}

J. W. Glen: There appear to be discrepancies between your activation energies for creep recovery and those reported by Jones and Brunet (and I suspect also those of Joncich and others) on single crystals and Sinha on polycrystals. However you have indicated that this may result from use of a different variable. Can you indicate whether you think your results agree or disagree with these other reports? If so, is this indication of a difference between polycrystals and single crystals?

P. Duval: I think that the results found in this study agree with the ones found on single crystals by Jones and Brunet (1978). The activation energies $U_{\mathrm{o}}$ measured by them probably correspond to the activation energy of the rate-controlling dislocation mechanism. This is not the case for polycrystals owing to strain hardening. Indeed, at low stresses, the dislocation velocity is given by:

$$
\frac{\mathrm{d} x}{\mathrm{~d} t}=\beta \exp \left[-\frac{U_{\mathrm{o}}}{k T}\left(\sigma_{\mathrm{a}}-\sigma_{\mathrm{i}}\right)\right],
$$

when $\sigma_{\mathrm{a}}$ is the applied stress and $\sigma_{\mathrm{i}}$ the internal stress produced by the elastic interaction of dislocations. If we assume that $\sigma_{\mathrm{i}}$ is proportional to $x$, the dislocation movement is then given by:

$$
\frac{\mathrm{d} x}{\mathrm{~d} t}=\beta \exp \left[-\frac{U_{\mathrm{o}}}{k T}\left(\sigma_{\mathrm{a}}-\gamma x\right)\right],
$$


but there is a distribution of values of $\gamma$. In this case, the activation energy for the creep does not correspond to the true activation energy for the process controlling the dislocation motion. As shown by Duval (1 977), logarithmic creep is followed by Andrade creep when the recovery process occurs. Steady-state creep is obtained when the strain-hardening rate is equal to the recovery rate. Following this model, the activation energy of steady-state creep corresponds to that of the recovery state. On the other hand, these results have been found for temperatures above $-12^{\circ} \mathrm{C}$.

R. W. Whitworth: Could you explain how you know the value of the parameter $n$ ?

Duval: The value of the parameter $n$ is obtained if we know the variation of $q^{-1}$ (or the variation of anelastic strain) with frequency. If the values of anelastic strain are plotted against unloading period (time $t=\mathrm{I} / 4 f$ ) with log-log coordinates, the slope of the curve is not constant. Indeed, the anelastic strain is given by

$$
\epsilon_{\mathrm{a}}=\frac{\Delta \tau}{h} \log (\mathrm{I}+\alpha t)
$$

but for a limited range of time $t$ around the value of about I ooo s, the parameter $n$ is about 0.2 .

\section{REFERENGES}

Duval, P. 1977. Lois du fluage transitoire ou permanent de la glace polycristalline pour divers états de constrainte. Annales de Géophysique, Tom. 32, No. 4, r 976 , p. 335-50.

Jones, S. J., and Brunet, J.-G. I978. Deformation of ice single crystals close to the melting point. Fournal of Glaciology, Vol. 21, No. 85 , p. $445-55$. 